\title{
Analisis Terhadap Metode Kuliah Daring dan Biaya Tranposrtasi Mahasiswa Indonesia Dalam Masa Pandemi COVID-19
}

\section{Analysis on the Method of Online Learning and Transportation Budgets from Indonesian Students During the Pandemic COVID-19}

\author{
Esther Sanda Manapa ${ }^{1)}$, Eliyah Acantha M Sampetoding ${ }^{2 *)}$, Monica Natalin $^{2)}$, Benardo Sinambela ${ }^{3)}$, \\ Dwi Ivana L Sitohang ${ }^{4)}$, Yusrih Anugerah M Ambabunga ${ }^{5)}$, Valian Yoga P Ardhana ${ }^{6)}$ \\ ${ }^{1)}$ Depik-FIKP, Universitas Hasanuddin, Kota Makassar \\ ${ }^{2)}$ Teknik Informatika, STIK Rajawali Talaud, Kabupaten Talaud \\ ${ }^{3)}$ Pengurus Pusat, Gerakan Mahasiswa Kristen Indonesia, Jakarta \\ 4) Pengurus Pusat, Perhimpunan Mahasiswa Katolik Republik Indonesia, Jakarta \\ ${ }^{5)}$ Teknik Elektro, Fakultas Teknik Universitas Kristen Indonesia Toraja, Toraja Utara \\ ${ }^{5)}$ Teknologi Informasi, Universitas Qamarul Huda Badaruddin, Kabupaten Lombok Tengah
}

* Penulis Korespendensi : eacantha@gmail.com ${ }^{2}$

\begin{abstract}
ABSTRAK
Penelitian ini bertujuan untuk menganalisis pengaruh dari pandemi Covid-19 terhadap aplikasi yang digunakan dan pengeluaran biaya mahasiswa selama pandemi. Pandemi Covid-19 menyebabkan pemerintah melalui Kemendikbud mengumumkan kegiatan belajar mengajar dilaksanakan dari rumah dengan metode daring. Terdapat beberapa keluhan dengan penggunaan metode daring salah satunya pendapat mengenai kenaikan biaya untuk pembelian pulsa paket data. Pendapat tersebut mengatakan bahwa pengeluaran mahasiswa bertambah karena pembelian pulsa paket data. Penelitian ini mencoba melakukan survei dan analisis khususnya membandingkan biaya mahasiswa sebelum dan sesudah covid-19. Selama pandemi, Mahasiswa mengeluarkan biaya pulsa lebih banyak dari sebelum pandemii yakni sebesar $10.8 \%$ pada pengisian pulsa. Tetapi terungkap bahwa pengeluaran biaya mahasiswa masa pandemi lebih sedikit dari sebelum pandemi dengan persentase terkecil 46.9\%. Aplikasi yang sering digunakan pada metode kuliah online yakni Google Classroom dengan $74,7 \%$, Zoom $67 \%$, dan WAG 35,3\%. Diharapkan penelitian awal ini dapat mendukung dan memberi masukan bagi pengambil kebijakan di institusi pendidikan pada perkuliahan selama pandemi berlangsung.
\end{abstract}

Kata Kunci : Biaya, Kuliah Online, Mahasiswa Indonesia, Covid-19

\section{ABSTRACT}

This study aims to analyze the effect of the Covid-19 pandemic on the applications and student expenditure during the pandemic. The Covid-19 pandemic caused the government through the Ministry of Education and Culture to announce teaching and learning activities carried out from home using the online method. There are several complaints with the use of online methods, one of which is opinion about the increase in fees for the purchase of data package pulses. The opinion said that student spending increased due to the purchase of data package pulses. This study tries to conduct a survey and analysis specifically comparing student costs before and after co-19. During a pandemic, students spend more credit than before the pandemic which is $10.8 \%$ on topping up. But it was revealed that spending on pandemic students was less than before the pandemic with the smallest percentage of 46.9\%. While applications that are often used in online lecture methods are Google Classroom with 74.7\%, Zoom 67\%, and WAG 35.3\%. It is hoped that this initial research can support and provide input to policy makers in education institutions during lectures during the pandemic.

Keywords: Budgets, Online Learning, Indonesian Students, Covid-19 


\section{PENDAhUluan}

Pandemi Covid-19, yakni mutan virus corona dari SARS sedang melanda dunia, termasuk Indonesia. Data per- 10 April 2020, hampir semua provinsi di Indonesia telah positif terpapar Covid-19 (Corona Virus Diseases-19). Berkenan hal tersebut Pemerintah Pusat dan Pemerintah Provinsi telah menganjurkan pembatasan interaksi fisik (physical distancing) dan memberlakukan social distancing melalui suatu kebijakan yang disebut Pembatasan Sosial Berskala Besar (PSBB) [1].

Kebijakan pemerintah mengenai PSBB, adalah suatu tindakan untuk memutuskan mata rantai penyebaran Covid19. Tindakan tersebut dinyatakan dalam bentuk konsep work from home (WFH) bagi pegawai/pekerja dan pembelajaran daring bagi pelajar dan mahasiswa

Sebagaimana suatu kebijakan biasanya memiliki dampak, maka kebijakan PSBB tersebut juga berdampak pada proses pembelajaran di dunia pendidikan, dari tingkat pendidikan dasar hingga perguruan tinggi. [2].

Pemerintah melalui Kementrian Pendidikan dan Kebudayaan (Kemendikbud) mengeluarkan Surat Edaran no 3 tahun 2020 tentang pencegahan Covid19 pada satuan pendidikan pada 9 Maret 2020 dan Surat Edaran Sekjen Kemendikbud no 36603/A.A5/OT/2020 pada 15 Maret 2020. Surat keputusan Kemendikbud tersebut dalam rangka upaya pencegahan dan penyebaran pandemi covid19 adalah suatu kebijakan pemerintah dalam physical distancing bagi dunia pendidikan [3].

Physical distancing bertujuan untuk memutus penyebaran wabah, membuat perubahan dari pendidikan format yang seyogianya tatap muka menjadi belajar dari tempat domisili masing-masing dengan sistem online dengan pemberlakuan skala nasional [4]. Pembelajaran online menyebabkan banyak mahasiswa dan dosen kembali ke daerah atau kampung halaman masing-masing. Pelaksanaan pembelajaran online ini perlu dipertimbangkan dan disesuaikan dengan perbedaan karakteristik di setiap area wilayah Indonesia sebagai negara kepulauan, bahari ataupun maritim..

Banyaknya keluhan dari mahasiswa dan dosen yang masih kesulitan melakukan pembelajaran sistem online akibat wilayah domisili merupakan daerah hinterland dengan karakteristik pegunungan, ataupun daerah pesisir dengan infrastruktur yang belum memadai dari aspek tuntutan teknologi daring yang digunakan. Profil dunia pendidikan sebagai negara maritim terbesar di dunia harus mampu mengikuti tuntutan jaman di era digital [5]. Pembelajaran sistem online selama masa pandemi covid-19 adalah sebuah tantangan pemimpin digital di Abad 21 [6].

Pengaruh pembelajaran daring [7] pada mahasiswa membuat adanya sebuah kultur baru dalam sistem pendidikan di Indonesia. Khususnya di institusi pendidikan, didorong untuk melaksanakan blended learning, yakni media pembelajaran online menggunakan aplikasi seperti zoom, whatsapp, google classroom, webex, maupun media sosial lainnya. Penggunaan aplikasi tersebut menghubungkan dosen dan mahasiswa sehingga proses pembelajaran dapat berjalan dengan semestinya di tengah pandemi virus covid-19 [4].

Pada pembelajaran di Indonesia terdapat beberapa metode yang dalam mengetahui peserta didik [8] yang terdampak terhadap kegiatan pembelajaran online di berbagai perguruan tinggi [9] Pembelajaran sistem online menjadikan teknologi menjadi kunci pelaksanaan pembelajaran yang menjembatani dosen dan mahasiswa. Literasi teknologi pemiliki peran penting dalam keterlaksanaan pembelajaran online selama pandemi Covid-19 [10]. Interaksi antara dosen dan mahasiswa sesuai aturan Dikti (pendidikan tinggi) harus melalui blended learning selama masa pandemi berlangsung.

Pada pelaksanaan blended learning terdapat beberapa hambatan di masa pandemi covid-19 [11], dosen harus mengingatkan para mahasiswa untuk menyalakan video mereka, dengan tujuan mahasiswa merasa bertanggung jawab untuk memperhatikan materi pembelajaran dan menghindari gangguan yang muncul ketiak belajar dari rumah. Dosen harus mengasah kemampuan teknik komunikasi mereka melalui layar, seperti memastikan suara, cahaya dan video yang nampak berkualitas dengan baik. Adanya video secara langsung, berguna untuk mendorong mahasiswa terlibat dalam kelas yang sedang berlangsung. Penggunaan teknologi materi pembelajaran secara audio visual ataupun video seiring kebutuhan paket pulsa data. Akibatnya kegiatan pembelajaran secara online tersebut dapat terlaksana dengan baik, apabila dukungan kuota internet yang cukup dan sesuai. Berkenan hal ini, maka faktor kurangnya kuota pulsa data dianggap sebagai salah satu kesulitan mahasiswa untuk melaksanakan pembelajaran. 
Beberapa perguruan tinggi menyediakan subsidi dan bekerjasama dengan operator telekomunikasi untuk mendukung kuota paket, tetapi tidak semua perguruan tinggi dapat melakukan hal ini. Alasan kekurangan kuota paket pada peserta didik dalam hal ini mahasiswa, bahwa kekurangan biaya untuk membeli pulsa paket data.

Kemendikbud juga menyatakan bahwa pembelajaran jarak jauh akan menjadi permanen, namun dalam sistem teknologi hybrid model. Teknologi dapat dimanfaatkan untuk melakukan berbagai macam modeling kegiatan belajar sebagai teknologi yang dapat memberikan kesempatan luas dan efisiensi bagi institusi pendidikan baik sebagai owner ataupun user .

Berdasarkan uraian di atas, maka penelitian ini bertujuan menganalisis metode kuliah daring dan pengeluaran biaya transportasi mahasiswa Indonesia selama masa pandemi Covid-19. Berbagai keluhan yang sebelumnya disampaikan mengenai biaya pulsa khususnya kuota internet yang jadi persoalan bagi mahasiswa akan dianalisis dan dibandingkan sebelum dan sesudah masa pandemi. Penerapankuliah daring dan kendala yang selama ini dialami dari aspek mengenai metode dan biaya perlu diteliti melalui kajian ilmiah dan survei secara langsung.

\section{Metodologi}

Jenis penelitian ini adalah kualitatif menggunakan data primer dan data sekunder. Sumber data primer berasal dari hasil analisis instrumen berupa kuesioner online dengan sampel penelitian yaitu 388 mahasiswa-mahasiswi Indonesia yang tersebar di 12 provinsi sebagai responden. Kriteria responden yang dinyatakan memenuhi syarat dalam penelitian ini adalah mereka yang masih berstatus sebagai mahasiswa/i aktif di seluruh perguruan tinggi yang ada di Indonesia. Sumber data sekunder diperoleh melalui penelusuran literatur, artikel, situs internet, ataupun jurnal ilmiah yang ada hubungannya dengan topik penelitian. Sementara yang menjadi variabel dalam penelitian ini adalah aplikasi yang digunakan dalam kuliah daring, pengeluaran pulsa sebelum dan sesudah pandemi covid-19, serta pengeluaran transportasi sebelum dan sesudah pandemi covid-19. Keseluruhan data diolah sesuai dengan kebutuhan model penelitian. Hasil data dianalisis dengan analisis deskriptif untuk mengetahui frekuensi penyebaran jawaban pada setiap item pertanyaan yang berhubungan dengan variabel penelitian.

\section{A. Model Penelitian}

Mengacu pada model Miles dan Huberman dalam Prastowo [12], adapun penjabaran data dalam penelitian ini dilakukan dengan teknik sebagai berikut:

\section{Data reduction (Reduksi data)}

Reduksi data berlangsung terus-menerus selama penelitian. Pada tahap ini, peneliti melakukan pengkategorian data (coding) dan interprestasi data.

2. Data display (Penyajian data)

Pada tahap ini, peneliti mendeskripsikan informasi yang telah diklasifikasikan yang kemudian dibentuk simpulan dan selanjutnya simplan tersebut disajikan.

3. Conclusion/Veryving (Penarikan simpulan)

Pada tahap ini, peneliti menarik simpulan, merumuskan alur kausalitas dari fenomena yang mungkin ada, kemudian melakukan verifikasi dengan cara mencocokkan dengan pengamatan yang dilakukan peneliti pada saat penelitian.

\section{Triangulasi}

Triagulasi adalah teknik pemeriksaan data untuk keperluan pengecekan atau sebagai pembanding terhadap data yang telah diperoleh. Agar validasi data tetap terjaga, peneliti melakukan triangulasi sumber yaitu teknik pengecekan data yang dilakukan dengan cara mengecek data yang telah diperoleh melalui sumber yang menjadi responden (objek penelitian). Data yang telah diperoleh dideskripsikan, dikategorisasikan, berdasarkan aspek pandangan yang sama, mana yang berbeda, dan mana yang spesifik dari sumber yang menjadi responden (objek penelitian).

\section{B. Rumusan Masalah}

Adanya Pandemi mengakibatkan pembelajaran daring, namun belum afektif akibat kendala biaya kuota yang dianggap cukup mahal, sehingga diperlukan evaluasi pada metode kuliah daring dan aspek efek biaya transportasi mahasiswa. pertanyaan penelitian, yang timbul:

(1) Aplikasi apakah yang menjadi pilihan favorit?

(2) Seberapa besarkah pengeluaran biaya transportasi sebelum dan sesudah pandemi bagi mahasiswa perbulan? 
(3) Seberapa besarkah biaya pemakaian pulsa/ kuota internet sebelum dan sesudah pandemi bagi mahasiswa perbulan?

Kemudian tujuan dari penelitian:

1 Mencari tahu adanya kontribusi metode kuliah daring terhadap efisiensi pengeluaran biaya transportasi mahasiswa Indonesia dalam masa pandemi covid-1.

2 Mencari tahu penerapan metode kuliah daring masih perlu dilanjutkanatau tidak.

\section{Penelitian Awal}

Penelitian menganalisis biaya pengeluaran mahasiswa Indonesia ini selama masa covid19 adalah ide baru agar stakeholder mendapatkan pengetahuan yang baik. Stakeholder dapat mengelola mahasiswaa sebagai aset penting institusi pendidikan yang dapat menciptakan keunggulan kompetitif [13] bagi lulusannya dengan teknologi pembelajaran blended learning.

\section{HaSil dan PEMbahaSAN}

Hasil kuesioner dianalisis dan dibagi dalam beberapa bagian yakni (A) Aplikasi dan Kondisi Pembelajaran Daring, (B) Biaya Pulsa Paket Data, (C) Biaya Transportasi, dan (D) Tingkatan level Kesulitan Perkulihaan Daring

\section{A. Aplikasi dan Kondisi Pembelajaran Daring}

Pada terdapat Aplikasi dan Kondisi Pembelajaran Daring pertama dilakukan survei pada aplikasi yang sering digunakan dalam kegiatan belajar mengajar mahasiswa dan kendala yang dirasakan oleh mahasiswa.

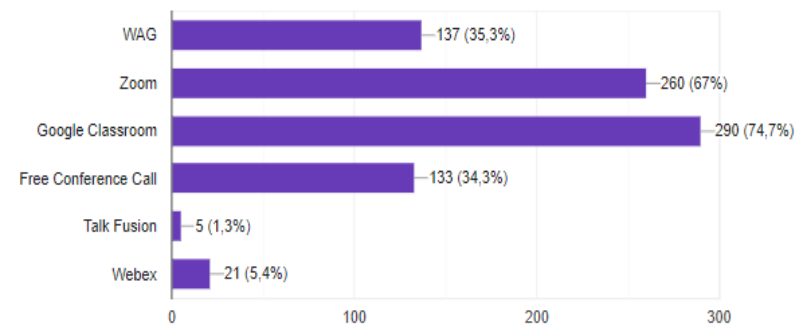

Gbr.1 Grafik aplikasi yang digunakan oleh mahasiswa

Berdasarkan grafik di atas, secara keseluruhan aplikasi yang digunakan oleh mahasiswa dan dosen dalam kuliah daring top 6 aplikasi adalah Google Classroom. Penggunaan aplikasi dengan urutan sebagai Google Classroom 74,7\%, kedua Zoom
67\%, WA Group 35,3\%, Free Conference Call 34,3\%, Webex 5,4\% dan terakhir Talk Fusion 1,3\%. Pada grafik terlihat bahwa produk aplikasi yang digunakan semuanya berasal dari luar, padahal sudah ada beberapa produk dalam negeri yang bisa digunakan misalnya aplikasi CloudX dari Telkomsel. Hasil dari suvei diperlihatkan bahwa aplikasi Google Classroom dan Zoom mendominasi kegiatan belajar mengajar yang dilaksanakan oleh mahasiswa dan dosen.

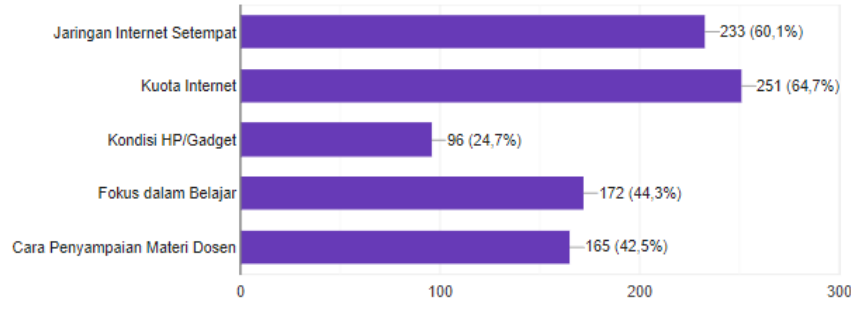

Gbr.2 Grafik kendala yang dirasakan oleh mahasiswa

Berdasarkan grafik di atas, secara keseluruhan terdapat lima kendala yang dirasakan oleh mahasiswa dalam melaksanakan perkulihaan online. Kendala utama dari mahasiswa yakni Kuota Internet dengan besar keluhannya sebesar 64,7\%. Selanjutnya secara berurutan adalah Jaringan internet sebesar $60,1 \%$, Fokus dalam belajar 44,3\%, Cara penyampaian materi dosen $42,5 \%$ dan Kondisi HP/Gadget sebesar 24,7\%. Hasil survei memperlihatkan bahwa kuota internet adalah alasan utama mahasiswa sebagai kendala dalam perkulihaan online.

\section{B. Biaya Pulsa Paket Data}

Pada terdapat lima buah pilihan yakni (Pilihan 1) pengeluaran kurang dari Rp. 50,000,- (Pilihan 2) antara Rp. 50,000,- sampai Rp. 100.000,- (Pilihan 3) 100.001 sampai 150.000,- (Pilihan 4) 150.001 sampai 200.000,-, dan terakhir (Pilihan 5) diatas Rp. 200.001.
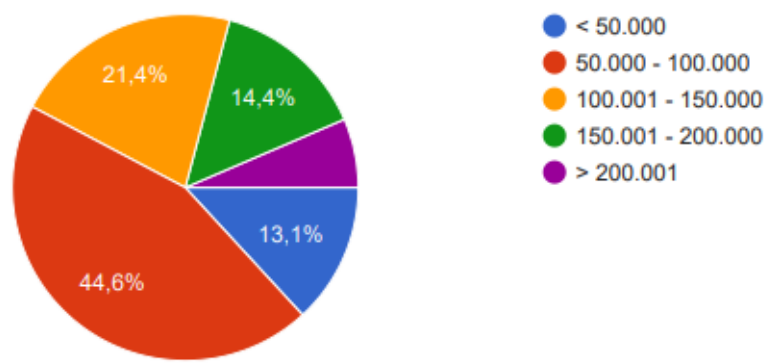

Gbr.3 Grafik pengeluaran pulsa sebelum pandemi 
Berdasarkan grafik Gbr.3 di atas, diketahui pengeluaran mahasiswa pada Pilihan A berjumlah 13,1\%; pada Pilihan B berjumlah 44,6\%; Pilihan C berjumlah 21,4\%; pada Pilihan D berjumlah 14,4\% dan Pilihan E berjumlah 6,4\%.

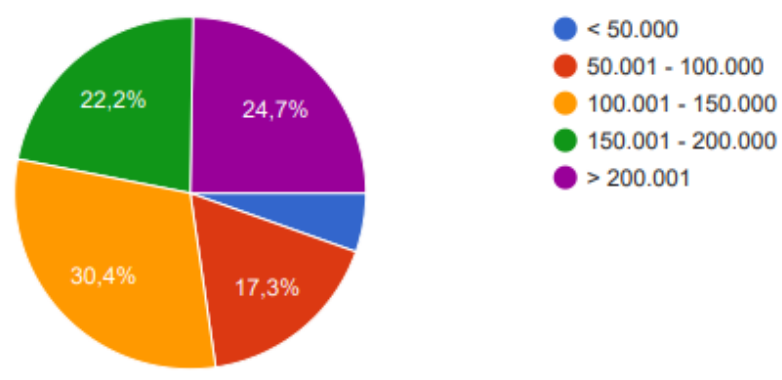

Gbr.4 Grafik pengeluaran pulsa saat pandemi

Berdasarkan grafik Gbr.4 di atas, diketahui pengeluaran mahasiswa pada Pilihan A berjumlah 5,4\%; pada Pilihan B berjumlah 17,3\%; Pilihan C berjumlah $30,4 \%$; pada Pilihan D berjumlah 22,2\% dan Pilihan E berjumlah 24,7\%.

Perbandingan antara grafik Gbr.3 dan grafik Gbr.4 memperlihatkan kenaikan biaya pulsa data sesudah pandemi terjadi. Hal tersebut terlihat pada Pilihan A sebelum pandemi persentase nya lebih banyak dari persentase saat pandemi. Pada Pilihan E juga terjadi kenaikan persentase pengeluaran mahasiswa saat pandemi dibandingkan sebelum pandemi. Sehingga dapat diambil kesimpulan bahwa secara umum mahasiswa mengalami kenaikan biaya pulsa data untuk melaksanakan perkulihaan daring.

\section{Biaya Transportasi}

Terdapat lima buah pilihan yakni (Pilihan A) pengeluaran kurang dari Rp. 200,000,- (Pilihan B) antara Rp. 200,001,- sampai Rp. 400.000,- (Pilihan C) 400.001 sampai 600.000,-, (Pilihan D) 600.001 sampai 800.000,-, dan terakhir (Pilihan E) diatas Rp. 800.000 .

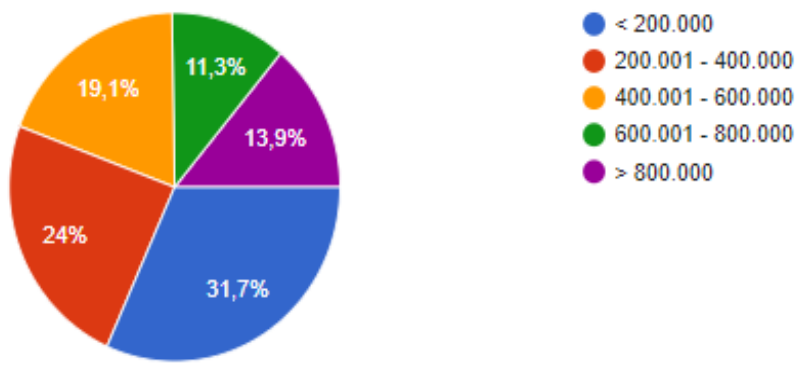

Gbr.5 Grafik pengeluaran transportasi sebelum pandemi
Berdasarkan grafik Gbr.5 di atas, diketahui pengeluaran mahasiswa pada Pilihan A berjumlah 31,7\%; pada Pilihan B berjumlah 24\%; Pilihan C berjumlah 19.1\%; pada Pilihan D berjumlah 11,3\% dan Pilihan E berjumlah 13,9\%.
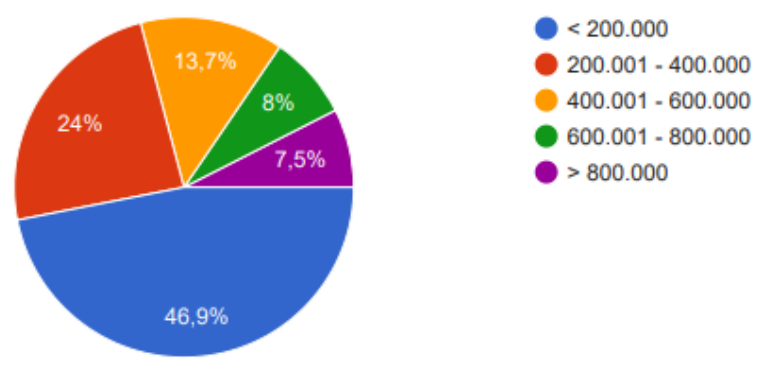

Gbr.6 Grafik pengeluaran transportasi saat pandemi

Berdasarkan grafik Gbr.6 di atas, diketahui pengeluaran mahasiswa pada Pilihan A berjumlah 46,9\%; pada Pilihan B berjumlah 24\%; Pilihan C berjumlah $13,7 \%$; pada Pilihan D berjumlah $8 \%$ dan Pilihan E berjumlah 7,5\%.

Perbandingan antara grafik Gbr.5 dan grafik Gbr.6 memperlihatkan kenaikan biaya pulsa data sesudah pandemi terjadi. Hal tersebut terlihat pada Pilihan A sebelum pandemi persentase nya lebih sedikit dari persentase saat pandemi. Pada Pilihan E juga terjadi penurunan persentase pengeluaran mahasiswa saat pandemi dibandingkan sebelum pandemi. Sehingga dapat diambil kesimpulan bahwa secara umum mahasiswa mengalami penurunan pengeluaran biaya untuk transportasi selama melaksanakan perkulihaan daring.

\section{Kesulitan Perkulihaan Daring}
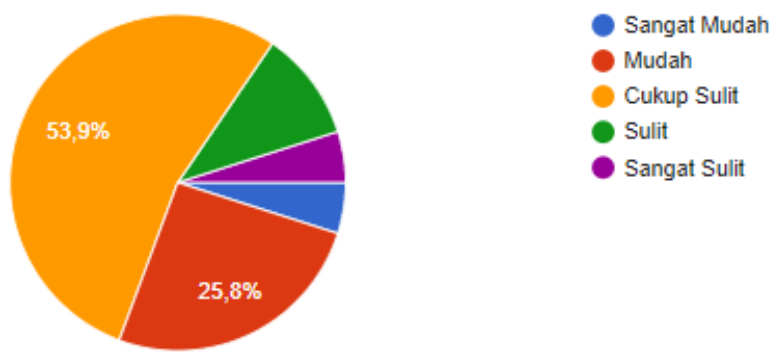

Gbr.7 Grafik kesulitan mahasiswa mengikuti perkulihaan Daring

Pada penelitian tahap awal ini dapat diketahui bahwa persentase kesulitan mengukit perkulihaan daring sebagai berikut, hasilnya pilihan sangat mudah sebesar 4,9\%, pilihan Mudah sebesar 25,8\%, Cukup Sulit sebesar 53,9\%, Sulit 10,6\%, dan sangat sulit $4,9 \%$. Hasilnya dapat diketahui bahwa mahasiswa 


\section{KESIMPULAN}

Dengan adanya penelitian ini, dapat disimpulkan bahwa:

1 Pandangan pengeluaran mahasiswa lebih banyak karena kuliah online tidak terbukti karena pengeluaran menggunakan transportasi justru lebih besar, sehingga biaya pulsa paket data sebenarnya dapat terpenuhi.

2 Mahasiswa tidak dapat menjadikan alasan tidak ada biaya paket pulsa karena dengan belajar daring biaya transportasi ke kampus tidak ada. Biaya tersebut dapat terkonversi, yakni biaya transportasi ke kampus menjadi biaya pulsa belajar di rumah atau tempat domisili masing-masing.

3 Hasil dari penelitian ini tidak hanya bermanfaat bagi dosen dikampus tetapi juga mampu memberikan pandangan kepada stakeholder pendidikan. Pandemi covid-19 membuat metode pembelajaran yang baru yakni tatap muka secara online, sehingga metode tersebut dapat menjadi pertimbangan untuk diteruskan.

Pada penelitian tahap awal ini diharapkan banyak penelitian lanjutan tentang dukungan belajar secara online baik secara E-Learning maupun Blended Learning. Hasil dari penelitian ini diharapkan bermanfaat bagi dosen di kampus tetapi juga mampu memberikan masukan kepada stakeholder pendidikan. Pandemi covid-19 membuat suatu kebiasaan metode pembelajaran yang baru yakni tatap muka secara online. Metode tersebut dapat menjadi pertimbangan untuk diteruskan, karena memiliki beberapa kelebihan tambahan, yakni:

- Jumlah peserta kuliah tidak dibatasi oleh ruang dan waktu

- Waktu pelaksanaan kuliah lebih mudah diatur

- Tidak ada waktu terbuang untuk perjalanan

Hanya ada juga kelemahan yang dimiliki sistem pembelajaran secara online ini, yakni:

- Kontak pribadi antara dosen dan mahasiswa terbatas

- Kemampuan berbeda antar mahasiswa peserta sulit teratasi.

Apapun juga selama belum ditemukannya vaksin untuk menghentikan pandemi covid, kualitas pendidikan nasional pada perguruan tinggi harus tetap berlangsung sambil melaksanakan standar kesehatan yang telah ditetapkan oleh WHO dan pemerintah.

\section{DAFTAR PUSTAKA}

[1] V. Maulita, "Futuready," 20 March 2020. [Online]. Available:

https://www.futuready.com/artikel/featured/workfrom-home/. [Accessed 23 July 2020].

[2] A. Bustomi, "IMPLIKASI COVID 19 TERHADAP PEMBELAJARAN DI PERGURUAN TINGGI," JURNAL TAWADHU, vol. 4, no. 1, pp. 1007-1017, 2020.

[3] S. K. Humas, "Sekertaris Kabinet Republik Indonesia," 15 Mei 2020. [Online]. Available: https://setkab.go.id/inilah-perubahan-kebijakanpendidikan-selama-masa-pandemi-covid-19/. [Accessed 2020 Juli 23].

[4] R. Pakpahan and Y. Fitriani, "ANALISA PEMANFAATAN TEKNOLOGI INFORMASI DALAM PEMBELAJARAN JARAK JAUH DI TENGAH PANDEMI VIRUS CORONA COVID19," Journal of Information System, Applied, Management, Accounting and Research, vol. 4, no. 2, pp. 30-46, 2020.

[5] E. S. Manapa, "Profil Dunia Kelautan Dalam Perspektif Siswa Indonesia di Tingkat Sekolah Dasar," Jurnal Penelitian Pendidikan, pp. 49-54, 2011.

[6] W. Darmalaksana, R. Y. A. Hambali, A. Masrur and Muhlas, "Analisis Pembelajaran Online Masa WFH Pandemic Covid-19 sebagai Tantangan Pemimpin Digital Abad 21," UIN Sunan Gunung Djati, Bandung, 2020.

[7] A. Purwanto, R. Pramono, M. Asbari, C. C. Hyun, L. M. Wijayanti, R. S. Putri and P. B. Santoso, "Studi Eksploratif Dampak Pandemi COVID-19 Terhadap Proses Pembelajaran Online di Sekolah Dasar," Edupsycouns, vol. 2, no. 1, pp. 1-12, 2020.

[8] S. Nurbaya, M. E. Sanda, A. Mardiana, M. N. Massi, V. Hadju and A. Nilawati, "Pengaruh metode pembelajaran mentorship terhadap keterampilan pemeriksaan Leopold pada mahasiswa DIII kebidanan," Jurnal Riset Kesehatan Poltekkes Depkes Bandung, vol. 12, no. 1, pp. 56-61, 2020.

[9] A. Latip, "PERAN LITERASI TEKNOLOGI INFORMASI DAN KOMUNIKASI PADA PEMBELAJARAN JARAK JAUH DI MASA PANDEMI COVID-19," Jurnal Edukasi dan 
Teknologi Pembelajaran, vol. 1, no. 2, pp. 107115, 2020.

[10] N. Husnah, M. Tamar, E. S. Manapa, W. Nontji, B. Bahar and S. Arifuddin, "Factor Analysis Related to Knowledge and Adolescent Attitudes about Menarche," IOSR Journal of Nursing and Health Science (IOSR-JNHS), vol. 9, no. 4, pp. 15, 2020.

[11] N. F. Azzahra, "Mengkaji Hambatan Pembelajaran Jarak Jauh di Indonesia di Masa Pandemi Covid19," Center for Indonesian Policy Studies, 2020.

[12] A. Prastowo, Metode Penelitian Kualitatif Dalam Perspektif Rancangan Penelitian, Jogjakarta: Arruzzmedia, 2012.

[13] T. W. Sagala, E. A. Manapa, V. Y. P. Ardhana and G. Lewakabessy, "Perbandingan Implementasi Manajemen Pengetahuan pada Berbagai Industri," JTIM: Jurnal Teknologi Informasi dan Multimedia, vol. 1, no. 4, pp. 327-335, 2020.

[14] E. S. Manapa, "Priority analysis and strategy fisheries transportation services in Pelabuhan Perikanan Ambon," Torani (Jurnal Ilmu Kelautan dan Perikanan), vol. 24, no. 3, pp. 1-9, 2014. 